\title{
The Impact of Local Government Investment on Corporate Decisions $^{22}$ Part 2
}

\author{
Puntillo Pina $^{23}$, Tenuta Paolo ${ }^{24}$
}

This work aims to provide evidence on the impact of public investment on local business decisions. In particular we want to see the effect of public investment on the development of local area - measured by GDP and employment - and therefore the effect that the development of the area determines the location decisions of businesses.

The paper continues from Part 1 (EJournal of Corporate Finance №1 (17) 2011). In this Part, is empirically tested the research hypothesis, through an econometric analysis, describing the models and variables used in the application of panel techniques, and presents the results of the estimates, while last section concludes with summary of some considerations.

JEL: $G 380$

Keywords: public investment, government, corporate decisions, policy making, local business decisions, development.

\section{Econometric analysis on the impact of local public expenditure for investments in the areas of economic growth}

Econometrics is the science and art of using economic theory and statistical techniques to analyze the data (Stock and Watson, 2009), in particular, through the econometric analysis we can study the causal effects between variables, to ascertain whether one or more variables (called independent variables or regressors or explanatory variables) cause another variable (dependent variable).

Here, the econometric analysis aims to determine whether, in the entity local "municipality", the levels of development of the territory are linked by a cause-effect relationship with positive expenditure on investment.

In theory, the framework under which it is believed that local public investment influence the development of the territories is to be found in economic theory and empirical analysis at both national and international level. Several studies have shown that public investment can trigger mechanisms of self-propelled economic development: they have, in other words, the effects on GDP, employment, average per capita income. That is to say that economic development is "affected", "determined" by the implementation of public investment.

Based on this however, it is interesting to estimate empirically the causal effect that is supposed to determine to what extent the level of development of territories is affected by capital expenditure. Such as development indicators will be used GDP per capita and the employment rate and therefore there will be empirically whether the investments are determinants of GDP and employment.

However, simply compare the levels of development with levels of investment spending means using the so-called naive procedure that is based on the assumption that the only factor that influences the level of development of territories (the dependent variable) is the investment expenditure .Therefore, in order to avoid producing biased estimates of the effect of interest is

\footnotetext{
${ }^{22}$ This paper is the result of shared thoughts of the authors. However, when drafting, the paragraph 1 is to be attributed to Pina Puntillo and the paragraph 2 is to be attributed to Paolo Tenuta.

${ }^{23}$ Researcher in Business Economics University of Calabria Department of business science

${ }^{24}$ Research Fellow in Business Economics University of Calabria Department of business science
} 
preferable to include in the regression model as explanatory variables (regressors) other factors that influence the level of economic development planning. In other words, it is necessary to provide adequate econometric model is a list of explanatory variables to avoid the problem of omission of relevant explanatory factors.

For this reason we apply a multivariate analysis, using, specifically, the multiple linear regression model, which is a linear regression model that includes multiple repressors, $\mathrm{X} 1, \mathrm{X} 2, \ldots$, $\mathrm{Xk}$. Each regressor is associated with a regression coefficient, $\beta 1, \beta 2, \ldots, \beta \mathrm{k}$, estimated with OLS. The coefficient $\beta 1$ represents the expected change of the dependent variable $Y$ associated with a unit change in $\mathrm{X} 1$, keeping constant the other regressors, the other regressors have a similar interpretation (Stock and Watson, 2009).

The multiple linear regression model is, in general terms, the following:

$$
Y_{i}=\beta_{o}+\beta_{1} X_{1 i}+\beta_{2} X_{2 i}+\ldots+\beta_{k} X_{k i}+u_{i} \quad i=1, \ldots, n
$$

where:

$\mathrm{Yi}$ is the ith observation of the dependent variable;

$\mathrm{X}_{1 \mathrm{i}}, \mathrm{X}_{2 \mathrm{i}}, \ldots, \mathrm{X}_{\mathrm{ki}}$ are the ith observations of each of the k regressors;

$\beta_{0}$ is the expected value of $Y$ when all $X$ are zero;

$\beta_{1}$ is the slope of $X_{2}, \beta_{2}$ is the slope of $X_{2}$, etc. $\beta_{1}$ coefficient represents the expected change of the dependent variable $Y$ that results from a unit change in $\mathrm{X} 1$, holding constant (controlling) $\mathrm{X}_{2}, \ldots$ , $\mathrm{X}_{\mathrm{k}}$; the coefficients of the other $\mathrm{X}$ are interpreted in a similar way;

ui is the statistical error.

In the notation just described have been used the words "holding constant", "controlling": is imperative to give an explanation. We already mentioned the problem of omitted variable bias in that it is explained that if you want to study the causal effect between a dependent variable and the variable of interest (explanatory), by inserting only two variables in the regression model, we could produce biased estimates.

If you want to correctly estimate the causal effect exerted by the variable on the dependent variable of interest is necessary to keep under control (ie, neutralize) the action exerted by distorting one or more additional variables, which is why they are defined control variables.

In essence, the control variables are variables that are not directly relevant, principally for the econometric analysis, but for which two conditions occur simultaneously: 1) are correlated with at least one of the regressors included in the model, 2) influence the dependent variable; these variables will be considered in the model because it can not produce biased estimates and therefore correctly estimate the causal effect of interest. In interpreting the regression model, the coefficients represent the change in each regressor, the effect that this regressor has on the dependent variable, "holding constant", "controlling" the other variables (such precisely control variables).

In the econometric model specified here, for the reasons stated above, were included control variables, the interpretation of the coefficient of each explanatory variable (or regressor or independent variable) then the others are control variables.

We now make explicit the independent variables included in the model.

The empirical research conducted in this paper is to explain the development of the region through a series of independent variables in particular are a total of four explanatory variables introduced in the model.

Considering these variables, the model estimated in this paper is therefore:

$$
Y_{i}=\beta_{o}+\beta_{1} X_{1 i}+\beta_{2} X_{2 i}+\beta_{3 i} X_{3 i}+\beta_{4} X_{4 i}+u_{i} \quad i=1, \ldots, n
$$

where:

$\mathrm{Yi}$ is the level of development of the territory of a generic common (statistical unit); will be used two indicators of development: GDP per capita and the employment rate will therefore be carried out two regressions:

1. Regression with $\mathrm{Yi}=$ per capita GDP

2. Regression with $\mathrm{Yi}=$ employment rate

$\beta_{0}$ is a constant that indicates a level playing field, keeping the other parameters fixed, the 
initial level of development;

$\beta_{1}, \beta_{2}, \ldots, \beta_{4}$ are the coefficients associated with the regressors and indicate that the impact of the independent variables $\mathrm{X}_{1}, \mathrm{X}_{2}, \ldots, \mathrm{X}_{4}$;

$\mathrm{X}_{1}, \mathrm{X}_{2}, \ldots, \mathrm{X}_{4}$ represent the explanatory variables of the model (regressors) unspecified below in Table 1;

$u$ is the stochastic component of the model, the margin of error, which includes everything that can not be explained by the deterministic model.

The explanatory variables of the model

\begin{tabular}{|c|l|}
\hline Explanatory variables & Description \\
\hline $\begin{array}{c}\text { Area }\left(X_{1}\right) \\
\text { Investment expenditure } \\
\left(X_{2}\right)\end{array}$ & $\begin{array}{l}\text { They are the expenses incurred by the implementation of } \\
\text { the investment. }\end{array}$ \\
\hline Staff costs $\left(X_{3}\right)$ & They are the costs incurred by the remuneration of staff. \\
\hline Center North $\left(X_{4}\right)$ & $\begin{array}{l}\text { It's a dummy inserted to represent the geographical area } \\
\text { of the local macro: takes the value } 1 \text { if the institution is } \\
\text { located in Center North, } 0 \text { otherwise. }\end{array}$ \\
\hline
\end{tabular}

With regard to spatial variables, we assume that a municipality with a land area larger, more resources management and development of the territory, where it is assumed that an increase in surface area could lead to increased levels of development.

It is also believed that the macro geographical area of the municipality may determine the level of development, since there is a historical territorial dualism Center North - South in terms of economic and social growth, in particular it is argued that in the north are significantly higher levels of development in the South.

What economic and financial variables have been considered capital expenditures and personnel. It is assumed that the former have a positive causal relationship with the levels of development while the second is a negative cause-effect relationship.

It is based on economic theories that have been widely discussed in paragraph 6 , which is believed to positively determine the investment levels of development; with regard to the reasons for the inclusion of the variable "staff costs", is necessary to recall briefly some considerations already made earlier.

The staff costs are "compulsory" as the local authority can not abstain by the honorable and this configuration makes it cost as much as the impact of these costs is marked within the current expenditure, the more budget appears stiff, reducing the ability to schedule and plan further investment and thus having negative effects on the development of the territory. It is expected, in fact, a negative correlation. analysis.

The following are a summary of the hypotheses that attempt to verify through empirical

Hypothesis H1: the increase of the surface, increases the level of regional development.

Hypothesis H2: the increase of investment spending, raise the level of regional development.

Hypothesis H3: the increase of personnel expenses, decreases the level of regional development.

Hypothesis H4: in Center North geographical macro-area shows a higher level of development, thus determining the location of the joint development of the territory.

Using these assumptions and considering the variables specified further in Table 1, supported by law and reviewed the literature on the subject, it aims to explain the definition and determinants of levels of territorial development in Italy.

In order to conduct the analysis were collected data relating to Italian municipalities considered for regional aggregation and was thus constructed a dataset, the time horizon of reference is $2004-2008$.

The dataset thus includes the 20 Italian regions, each region and each year observations in the 
dataset include the following:

1) spatial characteristics of the municipalities, such as the total area of the macro areas of expertise and geographical area ${ }^{25}$;

2) financial information derived from the certificates of financial statements of municipal government site and compiled by $\mathrm{Istat}^{26}$, in particular the accounting data derived from certificates of budget balances refer to:

investment expenditure: total expenditure of Title II of the "Capital expenditures", net of interventions 07 Capital transfers and 10 Concessions of credits and advances;

staff costs: total costs of the intervention 01del Title I;

3) the macroeconomic information: GDP per capita and employment rate, it is development indicators which will be considered in the regressions as dependent variables. Data were drawn from the Regional Economic Accounts retrieved from the site Istat 27.

Table 6 in Appendix shows the datasets that are shown on the sample observations to help estimate the model.

The following tables summarize the other hand, the descriptive statistics relating to financial information. This is useful information for analysis, allowing a better understanding of the structural characteristics of municipal budgets.

Table 2

Average characteristics of financial statements: investment expenditure

\begin{tabular}{|c|c|c|c|c|c|}
\hline Year & Observations & Mean & Std. Dev. & Min & Max \\
\hline 2004 & 20 & $1.40 \mathrm{e}+09$ & $1.10 \mathrm{e}+09$ & $1.63 \mathrm{e}+08$ & $4.59 \mathrm{e}+09$ \\
\hline 2005 & 20 & $1.16 \mathrm{e}+09$ & $7.79 \mathrm{e}+08$ & $1.38 \mathrm{e}+08$ & $3.25 \mathrm{e}+09$ \\
\hline 2006 & 20 & $1.01 \mathrm{e}+09$ & $7.56 \mathrm{e}+08$ & $1.46 \mathrm{e}+08$ & $2.96 \mathrm{e}+09$ \\
\hline 2007 & 20 & $9.61 \mathrm{e}+08$ & $7.41 \mathrm{e}+08$ & $1.27 \mathrm{e}+08$ & $2.74 \mathrm{e}+09$ \\
\hline 2008 & 20 & $9.79 \mathrm{e}+08$ & $7.56 \mathrm{e}+08$ & $1.53 \mathrm{e}+08$ & $2.83 \mathrm{e}+09$ \\
\hline
\end{tabular}

Table 2 shows an important fact: the average level of investment expenditures made by municipalities in the Italian-year period.

An analysis of trends in investment expenditure is observed in the five years analyzed, a downward trend. We move, in fact, from an average of $€ 1.40 \mathrm{e}+09$ in 2004 to an average of $€$ $9.61 \mathrm{e}+08$ in 2007 , only between 2007 and 2008 there was a slight increase in investment.

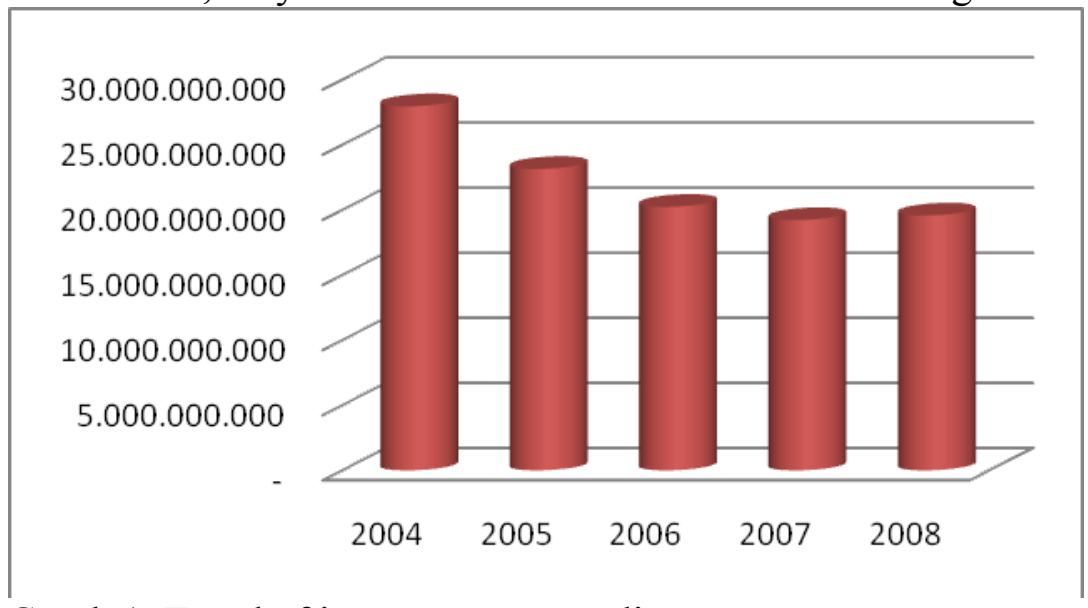

Graph 1. Trend of investment expenditure

Source: www.istat.it/istituzioni/entilocali/

\footnotetext{
${ }^{25}$ Data were collected from the site www.comuni-italiani.it

${ }^{26}$ www.istat.it/istituzioni/entilocali/ "Financial statements of the municipalities", in Tables of data. In particular, for each year (2004 to 2008) the reference table for the cost of investment is the $3 b$ - Analysis of investment, the board of reference for staff costs is the third - Analysis of current expenditure.

${ }^{27}$ www.istat.it/dati/dataset/20091111_00
} 
Average characteristics of financial statements: staff costs

\begin{tabular}{|c|c|c|c|c|c|}
\hline Year & Observations & Mean & Std. Dev. & Min & Max \\
\hline 2004 & 20 & $7.72 \mathrm{e}+08$ & $6.18 \mathrm{e}+08$ & $5.76 \mathrm{e}+07$ & $2.27 \mathrm{e}+09$ \\
\hline 2005 & 20 & $7.86 \mathrm{e}+08$ & $6.22 \mathrm{e}+08$ & $5.89 \mathrm{e}+07$ & $2.26 \mathrm{e}+09$ \\
\hline 2006 & 20 & $7.95 \mathrm{e}+08$ & $6.30 \mathrm{e}+08$ & $5.69 \mathrm{e}+07$ & $2.27 \mathrm{e}+09$ \\
\hline 2007 & 20 & $8.05 \mathrm{e}+08$ & $6.44 \mathrm{e}+08$ & $5.58 \mathrm{e}+07$ & $2.29 \mathrm{e}+09$ \\
\hline 2008 & 20 & $8.15 \mathrm{e}+08$ & $6.47 \mathrm{e}+08$ & $6.05 \mathrm{e}+07$ & $2.37 \mathrm{e}+09$ \\
\hline
\end{tabular}

Referring instead to the average levels of staff costs, we can see how it increases over the next five years, from $€ 7.72 \mathrm{e}+08$ in 2004 to $€ 8.15 \mathrm{e}+08$ in 2008 . The increased levels of staff costs can see immediately by the following graph:

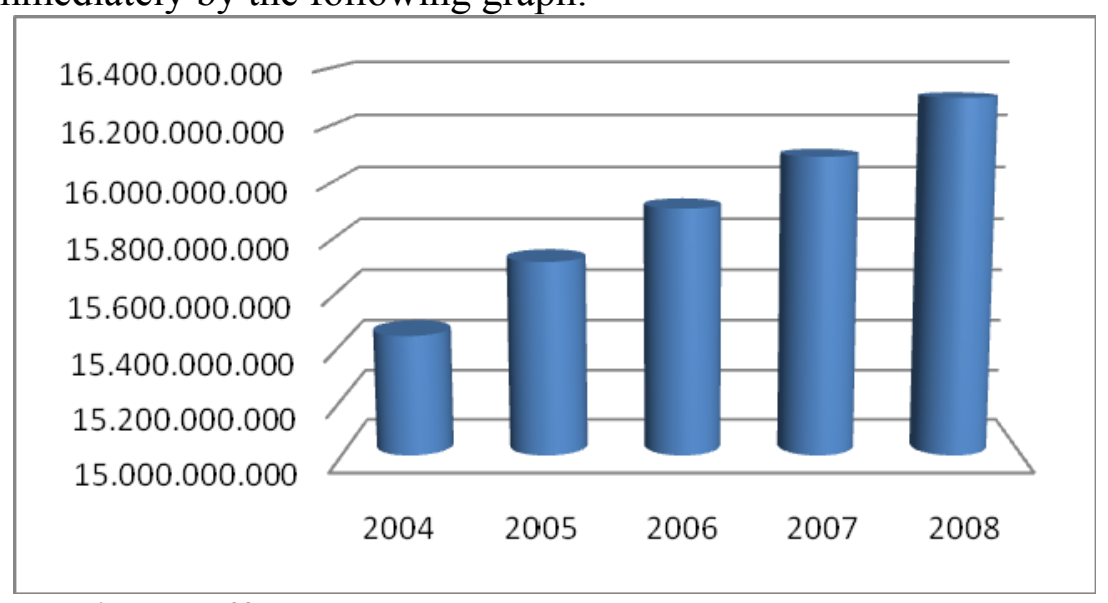

Graph 2. Staff costs

Source: www.istat.it/istituzioni/entilocali/

After representing tabular descriptive statistics relating to balance sheet data of the dependent variables used in the model, let us therefore to examine the results of the econometric analysis for which, as explained above, using a multivariate linear regression model estimated with the OLS method.

You need to make another point: Panel data were used (also called longitudinal data), the data are panel data covering more entities each of which is observed in two or more periods. To conduct this research were in fact collected data relating to Italian municipalities aggregated to 20 regions, each of which has been observed for 5 years, for a total of 100 observations. Having full availability to data for multiple time horizons, we can grasp not only the differences between the different entities (which could catch even using the cross-sectional data) but also can analyze the evolution of investment costs over time.

Among other things, the panel data regression is a method that allows you to control the presence of some types of omitted variables without actually observe them, and produces essentially unbiased estimates taking into account the effects of omitted (Baltagi, 2001).

There are three types of regression model with panel data:

1) model with fixed effects,

2) model with time effects,

3) the model with mixed effects.

In case you have chosen to use the model with temporal effects, considering "the best" for the case, since it allows to take into account the variability between entities and not just the inner to each entity, as is the case in model with fixed effects: given that Italian regions differ not only in them but there are substantial differences between individual regions, we believe that it is more appropriate to consider the temporal effects.

So an econometric analysis was conducted to study the determinants of levels of development of the territories - with a focus on verification of cause-effect relationship between development and 
investment costs - by using a multiple linear regression model with panel data and considering the so-called temporal effects. 2 regressions were performed:

1. Regression that considered as an indicator of development and therefore as the dependent variable, GDP per capita;

2. Regression which considers development as an indicator of the employment rate.

It exposes the following tables with the results of each regression, and then comment on them.

The regression 1 results

\begin{tabular}{lcccc}
\hline \multirow{2}{*}{ GDP per capita } & \multirow{2}{*}{ Coeff. } & $\begin{array}{c}\text { Robust } \\
\text { Std. Err. }\end{array}$ & \multirow{2}{*}{$P>|t|$} \\
\hline Area & 0.0306183 & 0.415335 & 0.74 & 0.463 \\
Investment expenditure & $1.22 \mathrm{e}-06$ & $4.39 \mathrm{e}-07$ & 2.77 & $0.007^{* * *}$ \\
Staff costs & $-1.26 \mathrm{e}-06$ & $6.89 \mathrm{e}-07$ & -1.83 & $0.071^{*}$ \\
Center North & 10782.98 & 489.6632 & 22.02 & $0.000^{* * *}$ \\
\hline
\end{tabular}

Table 5

The regression 2 results

\begin{tabular}{lcccc}
\hline Employment rate & Coeff. & $\begin{array}{c}\text { Robust } \\
\text { Std. Err. }\end{array}$ & $t$ & $P>|t|$ \\
\hline Area & $1.37 \mathrm{e}-06$ & $4.67 \mathrm{e}-07$ & 2.92 & $0.004^{* * *}$ \\
Investment expenditure & $1.39 \mathrm{e}-11$ & $5.59 \mathrm{e}-12$ & 2.49 & $0.015^{* *}$ \\
Staff costs & $-3.79 \mathrm{e}-11$ & $8.40 \mathrm{e}-12$ & -4.51 & $0.000^{* * *}$ \\
Center North & 0.1295048 & 0.0052772 & 24.54 & $0.000^{* * *}$ \\
\hline
\end{tabular}

Note: The asterisks placed next to the value of the regressors indicate the level of significance made by them, specifically:

$*=$ Significance at $10 \%$

$* *=$ Significance at $5 \%$

$* * *=$ Significance at $1 \%$

Reading the table 4 and 5 are very important results can be deduced.

For both regressions, all variables are statistically significant and confirm the hypotheses, except for the regressor surface which is not statistically significant for the regression which considers development as an indicator of GDP per capita. Apart from this isolated case, you can still argue that the model is interpreted as reliably able to fully explain the phenomenon that we wanted to prove.

We now analyze the results with reference to individual regressions.

Regression 1: Yi = GDP per capita

As mentioned earlier, this regression to the area is not statistically significant, therefore, was not tested the hypothesis $\mathrm{H} 1$ according to which the increase of the surface increases the levels of development, measured by GDP per capita in this. So the area is not a determinant of GDP per capita: looking to the p-value (the last column of the table), in fact, the value is greater than 0.10 , therefore the variable is not significant even at the level of $10 \%$.

All other variables included in the model are determinants of the dependent variable in question: we can therefore say that if the hypothesis $\mathrm{H} 1$ has not been verified, all the other assumptions underlying the research ( $\mathrm{H} 2, \mathrm{H} 3$ and $\mathrm{H} 4)$ were demonstrated.

Looking to the $\mathrm{p}$-value is arguable that are determinants of GDP per capita in the Italian towns: the investment expenditure (significant at 1\%), costs for staff (significant at 10\%) and geographical macro-area center north (significant at 1\%).

Looking at the coefficients of these variables, we can see that they are positive for investment expenditures and the dummy center north while is negative the for staff costs. It is therefore confirmed that an increase in investment expenditure increases GDP per capita, which increased staff costs reduces the per capita GDP and, finally, that the center north is more "developed" of the 
south. Please note that the variable central north is a dummy that is a binary regressor that takes only two values, 0 and 1: 1 if the municipality is located in the north, 0 otherwise; his interpretation is as follows: the municipalities of center north have a GDP per capita higher than in the south, this means that the geographical location of municipatilies determines development.

In detail, we can say that if the investment expenditure increased by $€ 1$, the GDP per capita increases by $€ 1.22 \mathrm{e}-06$ for the same variables, ie checking, holding constant the other explanatory variables included in the model; if the staff costs increased by $€ 1$, GDP per capita declined by $€$ $1.26 \mathrm{e}-06$ for the same variables and, finally, the municipalities located in the north have a level of per capita GDP higher than in the south of $€ 10.782,98$.

Finally, it should be emphasized that the inclusion of a large number of independent variables gives the model a high explanatory power. In fact, the $\mathrm{R}^{2}$ is 0.8461 , which means that the model developed is able to "explain" $84,61 \%$ of the variance of the phenomenon.

Regression 2: $\mathrm{Yi}=$ employment rate

In the regression which considers development as an indicator of the employment rate, all assumptions have been proven. We can therefore say that all the variables included in the model are determinants of the employment rate.

Looking to the p-value, in fact, are statistically significant (and therefore are determinant of the employment rate): the area (significant at 1\%), investment expenditure (significant at 5\%), staff costs (significant 1\%) and geographical macro-area center north (significant at 1\%).

Even the signs of the coefficients are those expected: positive for investment expenditure and the dummy center north, negative for staff costs.

It is therefore confirmed that an increase in investment spending increases the rate of employment, which increased spending on staff, the employment rate decreases and finally, that the center north is substantially more "developed" of the south, as most records high levels of employment.

In detail, we can say that if the area increases by $1 \mathrm{~km}^{2}$, the employment rate increases by 1.37e-06 for the same variables, ie checking, holding constant the other explanatory variables included in the model; if investment expenditure increased by $€ 1$, the employment rate increases by $1.39 \mathrm{e}-11$ for the same variables; if the staff costs increased by $€ 1$, the employment rate decreased by $€ 3.79 \mathrm{e}-11$ for the same variables and, finally, the municipalities located in the center north have an employment rate higher than the midday of 0.1295048 .

Finally, it should be emphasized that the inclusion of a large number of independent variables gives the model a high explanatory power. In fact, the $\mathrm{R}^{2}$ is 0.8672 , which means that the model developed is able to "explain" $86,72 \%$ of the variance of the phenomenon.

\section{Conclusions}

The results obtained in the econometric analysis confirms substantially all of the expectations about the determinants of levels of development in the Italian local authorities.

With the exception of a regression 1 in which the area is not statistically significant (while it is in regression 2), it can be argued that in both regressions of investment expenditure, expenditure on staff and the dummy center north have the expected sign and coefficients are statistically significant, which confirm the hypotheses: the level of development of the territories depends on the level of these variables.

Important consideration should be given to investment expenditure which are not only statistically significant but, as even more important is the positive sign of the coefficient: was the hypothesis H2, "as more of the costs of investment, increases the level of development the territory". In fact, the hypothesis of a direct relationship between investment expenditure and levels of development is that for which it was carried out this research work and made this econometric analysis, the main purpose was precisely to show that the investment costs are a determinant of regional development.

Other considerations are then made for staff costs, which were introduced in the econometric 
model to demonstrate that they have a negative effect on the development of the territory. This can be explained by the fact that the civil service has been used as a driving force in local government employment, without pondering the real effect that such action causes on the finances of the institution, budget balances, growth and macroeconomic indicators welfare and competitiveness of the territories.

So the levels of development of territories were determined by specific budget choices in the sense that policy makers have chosen to increase the staffing of institutions (with obvious repercussions on the levels of expenditure on staff) rather than investment spending. But decisions had to be geared more towards making the investment, given that they have effects on economic development in the area.

But business decisions have not only had a significant impact on local growth in recent years, they will also have implications for the future: the shift from a centralized system of public finance to public finance system involves a significant effect on self-finance of local authorities. If one considers, in fact, that with the implementation of fiscal federalism will be completely "cut" the government transfers which formerly constituted a substantial source of financing local public investments, one can understand how local authorities are now and find even more in the future in a situation "critical" in terms of availability of financial resources.

Fiscal federalism thus determines the criticality in terms of coverage of financial needs generated by investment spending: if the revenues derived in capital account will be more sources of funding, the structure is changed completely.

Nor can "push" too much borrowing as the local authorities must respect the constraints dictated by the need to keep the net raised annually by the Finance Laws and the Stability Pact.

Remain, to meet the financial needs generated by the investments, the so-called self-financing but even as regards the sources of self-financing is no shortage of problems: the budget surplus and income from disposals, are the result of unique sources, therefore we can not "rely" on these items to finance investment institutions premises. As regards the surplus of administration, we can certainly argue that it represents, in a dry spell more consistent with regard to transfers from the State and the Regions, one of the few tools available to the local authority has to finance investment; it is expressly intended, inter alia, the costs of investment in d), paragraph 3, Art. 187, Tuel. However, its coverage investment is directly related to its size, whether or not an emergency or short-term such that it would target other essential (eg for debts off balance sheet), and also the nature of the advanced may witness a less than optimal management, to the extent they have been stolen from citizens over those resources that the institution has proven to be able to spend.

Finally, it is noteworthy that, in the areas of the country characterized by a lower ability to pay, the revenue will decrease more and more of the institution.

In conclusion, it can be assumed that investment spending will decline further over the next few years precisely because of the lack of adequate resources to cover the financial needs generated by the investments, with noticeable impact on economic growth in the territories and on business location.

Thus, where still possible, and especially in the areas of the country characterized by weakness, economic weakness, the choices of the political organs of government - especially at the local level - should be geared to promote the realization of investments since these are the voices of budget (and not the staff costs) to have "capacity" of development. 
Appendix

Table 6

Dataset of observations on the Italian municipal administrations. Breakdown by region.

Observations for 5 years (2004-2008)

\begin{tabular}{|c|c|c|c|c|c|c|c|}
\hline Italian region & $\begin{array}{l}\text { Geographical } \\
\text { macro-area }\end{array}$ & Year & $\begin{array}{l}\text { GDP per capita } \\
\text { (in } €)\end{array}$ & $\begin{array}{l}\text { Employment } \\
\text { rate }\end{array}$ & $\begin{array}{c}\text { Area } \\
\left(\text { in } \mathrm{Km}^{2}\right)\end{array}$ & $\begin{array}{c}\text { Investment } \\
\text { expenditure } \\
\text { (in } €)\end{array}$ & $\begin{array}{l}\text { Staff costs } \\
\quad(\text { in } €)\end{array}$ \\
\hline Abruzzo & South & 2004 & $19.304,2$ & 0,38 & 10.798 & 432.358.384 & 291.091 .513 \\
\hline Basilicata & South & 2004 & $16.682,1$ & & 9.992 & 345.727 .436 & 148.251 .412 \\
\hline Calabria & South & 2004 & $15.480,7$ & & 15.080 & 824.025 .067 & 458.360 .634 \\
\hline Campania & South & 2004 & $15.531,7$ & 0,32 & 13.595 & 2.887.924.032 & 1.324 .466 .200 \\
\hline Emilia Romagna & Center North & 2004 & $29.314,5$ & 0,49 & 22.124 & 1.480 .414 .662 & 1.145 .445 .047 \\
\hline $\begin{array}{l}\text { Friuli Venezia } \\
\text { Giulia }\end{array}$ & Center North & 2004 & $26.147,2$ & 0,46 & 7.855 & 562.915 .947 & 356.091 .976 \\
\hline Lazio & Center North & 2004 & $28.768,9$ & 0,46 & 17.207 & 2.787 .950 .023 & 1.625.897.371 \\
\hline Ligu & Center I & 2004 & & & 5.421 & 671.948 .633 & 539.610 .442 \\
\hline Lombardia & Center North & 2004 & $31.059,5$ & 0,48 & 23.861 & 4.589 .147 .314 & 2.265 .823 .231 \\
\hline Marche & Center North & 2004 & $23.918,0$ & 0,47 & 9.694 & 557.610 .623 & 379.553 .139 \\
\hline Molis & South & 2004 & $.286,0$ & 0,36 & 4.438 & 163.292 .014 & 77.979 .002 \\
\hline Piems & Center North & 2004 & $5.351,7$ & & 25.399 & 2.138 .4 & 1.265 .560 .341 \\
\hline Puglia & South & 2004 & $15.712,1$ & & 19.362 & 2.069.385. & 740.145 .866 \\
\hline Sardegna & South & 2004 & $18.671,3$ & 0,3 & 24.090 & 1.570 .973 .826 & 419.293 .062 \\
\hline Sicilia & South & 2004 & & 0,2 & 25.708 & 1.595 & 3.920 \\
\hline Tosec & Center North & 2004 & $26.204,7$ & 0,46 & 22.997 & 1.443 .789 .029 & 1.113 .830 .988 \\
\hline $\begin{array}{l}\text { Trentino Alto } \\
\text { Adige }\end{array}$ & Center North & 2004 & $29.915,7$ & 0,49 & 13.607 & 1.163.797.411 & 392.924 .512 \\
\hline Umbria & Center North & 2004 & $22.583,0$ & 0,43 & 8.456 & 920.000 .950 & 241.638 .213 \\
\hline Valle d'Aosta & th & 2004 & & & 3.263 & & 310 \\
\hline Veneto & enter North & 2004 & 27.9 & 0,48 & 18.391 & 1.587 .9 & 925.505 .135 \\
\hline & & 2005 & & & 10.798 & 509 & .731 \\
\hline & & 2005 & & & 9.992 & 295.6 & 8.313 \\
\hline Calabr & South & 2005 & & & 15.080 & 930.806 .962 & 461.959 .204 \\
\hline Camp & & 2005 & & & 13.595 & 2.269 .9 & 1.467.170.948 \\
\hline Emili & Center North & 2005 & $29.784,1$ & 0,49 & 22.124 & 1.466 .694 .699 & 1.221 .083 .506 \\
\hline $\begin{array}{l}\text { Friuli } \\
\text { Giulia }\end{array}$ & Center North & 2005 & $26.967,8$ & 0,47 & 7.855 & 633.772 .820 & 388.532 .183 \\
\hline & Center North & 2005 & $29.280,0$ & 0,46 & 17.207 & 1.877 .788 .962 & 1.664 .395 .888 \\
\hline & & 2005 & & & 5.421 & 622. & 818 \\
\hline Lombardia & enter North & 2005 & & & 23.861 & 3.249 .410 .814 & 2.255 .119 .900 \\
\hline Marche & enter North & 2005 & & 0,46 & 9.694 & 549.106 .095 & 394.908 .409 \\
\hline & & 2005 & & & & & \\
\hline Piem & enter North & 2005 & & & 25.399 & 1.773. & 1.172 .362 .078 \\
\hline & & 2005 & & & 19.362 & 1.259 .929 .306 & 738.942 .084 \\
\hline Sardegna & & 2005 & & & 24.090 & & 414.457 .515 \\
\hline Sici & Sol & 2005 & & & 08 & 1.79 & 1.633 .030 .553 \\
\hline Toscan & Center North & 2005 & $26.634,9$ & 0,46 & 22.997 & 1.294 .516 .079 & 1.088 .359 .566 \\
\hline $\begin{array}{l}\text { Trentino Alto } \\
\text { Adige }\end{array}$ & Center North & 2005 & $30.278,6$ & 0,49 & 13.607 & 906.070 .935 & 421.291 .788 \\
\hline Umbria & Center $\mathrm{N}$ & 2005 & & 0,4 & 8.456 & 716.168 .580 & 237.191 .745 \\
\hline Valle d'Aosta & enter North & 2005 & & 0,47 & 3.263 & 137.871 .618 & 58.874 .554 \\
\hline Veneto & Center North & 2005 & & & 18.391 & 1.572 .778 .022 & 1.036 .582 .716 \\
\hline & & 2006 & & & & & \\
\hline & & 2006 & & & 9.992 & 301.294 .914 & 147.718 .314 \\
\hline Calabria & South & 2006 & 478,0 & 0,32 & 15.080 & 592.222 .710 & 474.070 .044 \\
\hline & & 2006 & & & 13.595 & 2.481.917.415 & 1.556 .919 .541 \\
\hline Emilia l & Center North & 2006 & $31.021,1$ & 0,50 & 22.124 & 1.276 .522 .042 & 1.237 .698 .419 \\
\hline $\begin{array}{l}\text { Friuli Venezia } \\
\text { Giulia }\end{array}$ & Center North & 2006 & $28.068,1$ & 0,48 & 7.855 & 479.274 .681 & 392.997 .894 \\
\hline & & 2006 & & & 17.207 & 1.879.974.527 & 1.643 .092 .535 \\
\hline Liguria & Center North & 2006 & $25.471,5$ & 0,41 & 5.421 & 487.358 .415 & 563.826 .474 \\
\hline
\end{tabular}




\begin{tabular}{|c|c|c|c|c|c|c|c|}
\hline Lombardia & Center North & 2006 & $32.356,3$ & 0,49 & 23.861 & 2.958 .159 .722 & 2.269 .821 .496 \\
\hline Marche & Center North & 2006 & $25.645,6$ & 0,47 & 9.694 & 459.127 .324 & 396.076 .663 \\
\hline Molise & South & 2006 & $19.002,8$ & 0,37 & 4.438 & 170.021 .345 & 84.464 .050 \\
\hline Piemonte & Center North & 2006 & $27.718,9$ & 0,46 & 25.399 & 1.426 .131 .812 & 1.173 .888 .327 \\
\hline Puglia & South & 2006 & $16.702,7$ & 0,32 & 19.362 & 1.471 .325 .358 & 762.236 .911 \\
\hline Sardegna & South & 2006 & $19.649,8$ & 0,37 & 24.090 & 788.063 .944 & 418.456 .686 \\
\hline Sicilia & South & 2006 & $16.723,0$ & 0,31 & 25.708 & 1.004 .575 .046 & 1.674 .588 .185 \\
\hline Toscana & Center North & 2006 & $27.599,8$ & 0,46 & 22.997 & 1.009 .668 .817 & 1.086 .499 .503 \\
\hline $\begin{array}{l}\text { Trentino Alto } \\
\text { Adige }\end{array}$ & Center North & 2006 & $31.266,7$ & 0,49 & 13.607 & 913.583 .246 & 390.245 .776 \\
\hline Umbria & Center North & 2006 & $23.724,9$ & 0,44 & 8.456 & 549.390 .097 & 239.858 .385 \\
\hline Valle d'Aosta & Center North & 2006 & $32.594,0$ & 0,47 & 3.263 & 145.738 .028 & 56.933 .721 \\
\hline Veneto & Center North & 2006 & $29.267,2$ & 0,48 & 18.391 & 1.379 .353 .791 & 1.036 .134 .260 \\
\hline Abruzzo & South & 2007 & $21.601,9$ & 0,39 & 10.798 & 425.155 .107 & 301.008 .306 \\
\hline Basilicata & South & 2007 & $18.698,5$ & 0,36 & 9.992 & 252.865 .711 & 143.490 .709 \\
\hline Calabria & South & 2007 & $16.937,9$ & 0,32 & 15.080 & 615.723 .312 & 470.873 .161 \\
\hline Campania & South & 2007 & $16.909,1$ & 0,31 & 13.595 & 2.254 .024 .425 & 1.524 .525 .736 \\
\hline Emilia Romagna & Center North & 2007 & $32.112,9$ & 0,51 & 22.124 & 1.231 .578 .727 & 1.244 .774 .337 \\
\hline $\begin{array}{l}\text { Friuli Venezia } \\
\text { Giulia }\end{array}$ & Center North & 2007 & $29.238,0$ & 0,48 & 7.855 & 512.754 .693 & 401.827 .754 \\
\hline Lazio & Center North & 2007 & $30.305,8$ & 0,46 & 17.207 & 2.331 .022 .418 & 1.693 .835 .853 \\
\hline Liguria & Center North & 2007 & $26.812,8$ & 0,42 & 5.421 & 441.328 .752 & 564.047 .105 \\
\hline Lombardia & Center North & 2007 & $33.442,5$ & 0,49 & 23.861 & 2.740 .867 .895 & 2.294 .408 .650 \\
\hline Marche & Center North & 2007 & $26.501,7$ & 0,48 & 9.694 & 379.207 .890 & 397.075 .003 \\
\hline Molise & South & 2007 & $19.950,6$ & 0,38 & 4.438 & 181.297 .014 & 80.503 .637 \\
\hline Piemonte & Center North & 2007 & $28.575,4$ & 0,47 & 25.399 & 1.358 .852 .270 & 1.172 .878 .977 \\
\hline Puglia & South & 2007 & $17.110,5$ & 0,33 & 19.362 & 1.007 .338 .581 & 734.295 .850 \\
\hline Sardegna & South & 2007 & $20.405,3$ & 0,37 & 24.090 & 740.283 .060 & 427.086 .766 \\
\hline Sicilia & South & 2007 & $17.178,7$ & 0,30 & 25.708 & 800.177 .383 & 1.801 .811 .859 \\
\hline Toscana & Center North & 2007 & $28.431,0$ & 0,46 & 22.997 & 1.072 .895 .872 & 1.090 .795 .329 \\
\hline $\begin{array}{l}\text { Trentino Alto } \\
\text { Adige }\end{array}$ & Center North & 2007 & $32.403,3$ & 0,49 & 13.607 & 1.088 .089 .526 & 407.647 .974 \\
\hline Umbria & Center North & 2007 & $24.493,3$ & 0,45 & 8.456 & 431.322 .355 & 240.374 .652 \\
\hline Valle d'Aosta & Center North & 2007 & $33.556,0$ & 0,48 & 3.263 & 126.575 .316 & 55.828 .810 \\
\hline Veneto & Center North & 2007 & $30.243,7$ & 0,48 & 18.391 & 1.233 .136 .871 & 1.044 .549 .579 \\
\hline Abruzzo & South & 2008 & $21.786,7$ & 0,39 & 10.798 & 353.473 .010 & 309.943 .622 \\
\hline Basilicata & South & 2008 & $19.081,5$ & 0,36 & 9.992 & 255.931 .423 & 149.591 .729 \\
\hline Calabria & South & 2008 & $16.895,5$ & 0,31 & 15.080 & 625.008 .966 & 492.744 .725 \\
\hline Campania & South & 2008 & $16.886,0$ & 0,31 & 13.595 & 2.152.736.956 & 1.596 .354 .915 \\
\hline Emilia Romagna & Center North & 2008 & $32.062,1$ & 0,51 & 22.124 & 1.164 .629 .769 & 1.259 .832 .678 \\
\hline $\begin{array}{l}\text { Friuli Venezia } \\
\text { Giulia }\end{array}$ & Center North & 2008 & $29.341,1$ & 0,48 & 7.855 & 485.241 .214 & 413.392 .314 \\
\hline Lazio & Center North & 2008 & $30.641,4$ & 0,45 & 17.207 & 2.489 .436 .005 & 1.403 .327 .185 \\
\hline Liguria & Center North & 2008 & $27.348,4$ & 0,42 & 5.421 & 503.630 .006 & 571.649 .048 \\
\hline Lombardia & Center North & 2008 & $33.424,8$ & 0,48 & 23.861 & 2.829.606.058 & 2.366 .042 .574 \\
\hline Marche & Center North & 2008 & $26.655,9$ & 0,47 & 9.694 & 403.795 .865 & 405.807 .000 \\
\hline Molise & South & 2008 & $20.370,0$ & 0,39 & 4.438 & 214.540 .265 & 89.480 .266 \\
\hline Piemonte & Center North & 2008 & $28.665,7$ & 0,46 & 25.399 & 1.327 .329 .800 & 1.222 .389 .489 \\
\hline Puglia & South & 2008 & $17.309,0$ & 0,33 & 19.362 & 901.723 .456 & 779.458 .879 \\
\hline Sardegna & South & 2008 & $20.591,1$ & 0,37 & 24.090 & 891.147 .570 & 451.199 .884 \\
\hline Sicilia & South & 2008 & $17.338,2$ & 0,30 & 25.708 & 839.659 .712 & 1.896 .250 .870 \\
\hline Toscana & Center North & 2008 & $28.746,8$ & 0,47 & 22.997 & 1.173 .034 .608 & 1.108 .529 .849 \\
\hline $\begin{array}{l}\text { Trentino Alto } \\
\text { Adige }\end{array}$ & Center North & 2008 & $33.238,8$ & 0,49 & 13.607 & 1.171 .372 .449 & 403.020 .294 \\
\hline Umbria & Center North & 2008 & $24.590,4$ & 0,44 & 8.456 & 392.681 .669 & 245.618 .169 \\
\hline Valle d'Aosta & Center North & 2008 & $34.154,6$ & 0,47 & 3.263 & 153.300 .283 & 60.497 .046 \\
\hline Veneto & Center North & 2008 & $30.347,3$ & 0,48 & 18.391 & 1.250 .806 .733 & 1.074 .441 .636 \\
\hline
\end{tabular}




\section{References}

1. Agenòr, P.-R. (2009), Infrastructure Investment and Maintenance Expenditure: Optimal Allocation Rules in a Growing Economy, Journal of Public economic Theory, 11(2) (2009) 233-250.

2. Aschauer, D. (1989a), Is Public Expenditure Productive?, Journal of Monetary Economics, 23 (1989a) 177-200.

3. Aschauer, D. (1989b), Does Public Capital Crowd Out Private Capital?, Journal of Monetary Economics, 24 (1989b) 171-188.

4. Atukuren, E. (2005), Interactions Between Public and Private Investment: Evidence from Developing Countries, Kyklos, 58(3) (2005) 307-330.

5. Aubert, S., Stephan, A. (2000), Regionale Infrastruktur Politik und ihre Auswirkung auf die Produktivität: ein Vergleich von Deutschland und Frankreich, Berlin: Wissenschaftszentrum, (2000).

6. Baldi, L. (2005), Investimenti: le disposizioni della finanziaria 2005 in materia di finanziamento, Azienditalia, 8 (2005) 509.

7. Baltagi, Badi, H. (2001), Econometric Analysis of Panel Data, Chichester: John Wiley \& Sons, (2001).

8. Barbero, M. (2005), Golden Rule: non è tutt'oro quel che luccica!, Le Regioni, 4 (2005) 675.

9. Barman, TR, Gupta, MR (2010), Public Expenditure. Environment and Economic Growth, Journal of Public economic Theory, 12(6) (2010) 1109-1134.

10. Barro, RJ (1991), Economic Growth in a Cross Section of Countries, The Quarterly Journal of Economics, 106(2) (1991) 407-443.

11. Barro, RJ, Sala-I-Martin, X. (1992), Convergence, The Journal of Political Economy, 100(2) (1992) 223-251.

12. Baxter, M., King, RG (1993), Fiscal Policy in General Equilibrium, American Economic Review, 83(3) (1993) 315-333.

13. Biehl, D. (1986), The contribution of infrastructure to regional development: final report, Luxembourg: Office for Official Publications of the European Communities, (1986).

14. Bose, N., Haque, ME, Osborn, DR (2007), Public Expenditure and Economic Growth: a disaggregated Analisys for Developing Countries, The Manchester School, 75(5) (2007) 533-556.

15. Buscema, S. (1971), Il bilancio, 1, Milano: Giuffrè, (1971).

16. Costa-Font, J., Rodriguez-Oreggia, E. (2005), Trade and the Effect of Pubic Investment on Regional Inequalities in Heterogeneously Integrated Areas, The World Economy, 28(6) (2005) 873-891.

17. D’Aries, C., D’Atri, A., Mazzara, L. (1998), Enti locali - Il sistema informativo contabile, Milano: Ipsoa, (1998).

18. D'Aristotile, E. (2000), Gli investimenti negli enti locali: la programmazione, la valutazione, la contabilizzazione, la scelta della fonte di finanziamento, Gorle: Cel, (2000).

19. D'Aristotile, E. (2004), La nozione di investimento e indebitamento dopo la legge finanziaria 2004, Azienditalia, 5 (2004) 323.

20. D'Aristotile, E. (2009), La nozione di investimento e di indebitamento nelle disposizioni normative riguardanti gli enti locali, in Amatucci, F., Pezzani, F., Vecchi, V. (a cura di) (2009), Le scelte di finanziamento negli enti locali, Milano: Egea, (2009).

21. Di Giacinto, V., Micucci, G., Montanaro, P. (2009), Effetti macroeconomici del capitale pubblico: un'analisi su dati regionali, Mezzogiorno e politiche regionali, Banca d'Italia, 2 (2009) 279-317.

22. Di Massa, P. (1989), Il finanziamento e la realizzazione delle opere pubbliche negli enti locali, Ceranesi: Maggi, (1989). 
23. Di Palma, M., Mazziotta, C. (2003), Infrastrutture, competitività e sviluppo: il caso italiano, Economia Italiana, 3 (2003) 534.

24. Eberts, RW (1986), Estimating the contribution of urban public infrastructure to regional growth, Working Paper, URL: http://www.clevelandfed.org/research/Workpaper

25. Eberts, RW (1990), Public infrastructure and regional economic development, Economic Review, 90(Q1) (1990) 15-27.

26. Fabiani, S., Pellegrini, G. (1997), Education, infrastructure, geography and growth: an empirical analysis of the development of italian provinces, Temi di discussione, Roma: Banca d'Italia, 323 (1997).

27. Farneti, F. (1998), Gestione e Contabilità dell'ente locale, Santarcangelo di Romagna: Maggioli, (1998).

28. Falcone, G. (1998), Il finanziamento degli investimenti negli enti locali, Guida normativa, Gorle: Cel, (1998).

29. Giacomelli, P. (1998), Programmazione e finanziamento degli investimenti, Azienditalia, 5(3) (1998) 135-136.

30. Giuranno, MG (2009), Regional income Disparity and the Size of the public sector, Journal of Public economic Theory, 11(5) (2009) 667-873.

31. Hankla, C., Downs, W. (2010), Decentralisation. Governance and the Structure of Local Political Institutions: Lessons for Reform?, Local Government Studies, 36 (6) (2010) 759783.

32. Hansen, M. (1965), Unbalanced Growth and Regional Development, Western Economic Journal, 4 (1965) 3-14.

33. Hirschmann, OA (1958), The Strategy of Economic Development, London: Yale University Press, (1958).

34. Iuzzolino, G. (2009), I divari territoriali di sviluppo in Italia nel confronto internazionale, Mezzogiorno e politiche regionali, Banca d'Italia, 2 (2009) 428.

35. Kemmerling, A., Stephan, A. (2002), The Contribution of Local Public Infrastructure to Private Productivity and its Political Economy: Evidence from a Panel of Large German Cities, Public Choice, 113(3-4) (2002) 403-424.

36. Marotta, G. (2004), La definizione di spesa in conto capitale e di investimento dopo la legge finanziaria 2004, La Finanza Locale, 5 (2004) 42.

37. Martinez Oliva, JC (2009), Riunificazione intertedesca e politiche per la convergenza, Mezzogiorno e politiche regionali, Banca d'Italia, 2 (2009) 479-502.

38. Mehrotra, A., Valila, T. (2006), Public Investment in Europe: Evolution and determinants in perspective, Fiscal Studies, 27(4) (2006) 443-471.

39. Morese, F. (1982), Metodologia decisionale nella programmazione degli investimenti pubblici, Economia pubblica, 9 (1982) 395.

40. ODCEC di Ivrea, Pinerolo e Torino (2008), Il finanziamento degli investimenti negli enti locali, Corso di formazione in materia di enti locali, $\mathrm{VI}^{\wedge}$ giornata, URL: http://www.odc.torino.it/public/convegni/con15541.ppt

41. Perloff, HS (1963), How a region grows: area development in the U.S. economy, New York: Committee for economic development, (1963).

42. Romp, W., De Haan, J. (2007), Public Capital and Economic Growht: a Critical Survey, Perspektiven der Wirtschaftspolitik, 8(S1) (2007) 6-52.

43. Sanchez-Robles, B. (2007), Infrastructure Investment and Growth: some empirical evidence, Contemporary Economic Policy, 16(1) (2007) 98-108.

44. Smith, B. (2008), Good governance and development, Public Administration and Development, 28(3) (2008) 251.

45. Stock, JH., Watson, MW (2009), Introduzione all'Econometria, Milano: Pearson Education Italia, (2009).

46. Tondini, E. (2008), Infrastrutture e sviluppo: un legame ancora da esplorare, AUR\&S, 11 (2008) 243. 